\title{
Cathepsin D stimulates the activities of secreted plasminogen activators in the breast cancer acidic environment
}

\author{
MARIE MAYNADIER ${ }^{1,3^{*}}$, REZA FARNOUD $^{3,4^{*}}$, PIERRE-JEAN LAMY ${ }^{5,6}$, VALÉRIE LAURENT-MATHA ${ }^{2,3,4,5}$ \\ MARCEL GARCIA $^{1}$ and HENRI ROCHEFORT ${ }^{2,3,4,5}$ \\ ${ }^{1}$ IBMM UMR 5247, University of Montpellier 1, University of Montpellier 2, ENSCM; \\ ${ }^{2}$ IRCM, Institut de Recherche en Cancerologie de Montpellier; ${ }^{3}$ INSERM U148 and U896; \\ ${ }^{4}$ University of Montpellier $1 ;{ }^{5} \mathrm{ICM} ;{ }^{6}$ Department of Biology, ICM, \\ Val d'Aurelle Paul Lamarque, Montpellier, France
}

Received May 21, 2013; Accepted June 26, 2013

DOI: 10.3892/ijo.2013.2095

\begin{abstract}
Two proteases cathepsin D (cath D) and urokinase plasminogen activator (uPA) are tissue markers associated with an increased risk of metastasis in breast cancer. We investigated whether cath $\mathrm{D}$, the major aspartyl protease overexpressed by breast cancer cells can trigger a proteolytic cascade via activation of plasminogens at the extracellular $\mathrm{pH}$ measured in hypoxic tumors. The effects of the aspartyl protease inhibitor pepstatin on the plasminogen activator (PA) system were analysed by conditioning media of human MDA-MB231 breast cancer cells at pH 6.6 and pH 7.4. Zymography analysis of culture media showed that pepstatin inhibited the secreted activity of tissue-type plasminogen activator (tPA) but not that of uPA. tPA was identified on the basis of the molecular weight, the immunoreactivity with relevant antibodies and the resistance to amiloride, a specific uPA inhibitor. The secreted tPA activity measured by a chromogenic assay in the presence of amiloride was also inhibited by pepstatin at $\mathrm{pH}$ 6.6. Surprisingly, pepstatin did not affect secreted tPA protein concentration but markedly increased the amount of the secreted plasminogen activator inhibitor-1 (PAI-1). We conclude that cath D overexpressed by these cells, stimulates at $\mathrm{pH}$ 6.6, but not at neutral $\mathrm{pH}$, the extracellular PA proteolytic activity indirectly via PAI-1 proteolysis. This suggests that cath $\mathrm{D}$ at acidic $\mathrm{pH}$ close to the hypoxic regions of solid tumors, contributes to trigger a proteolytic cascade facilitating cancer cell invasion and metastasis.
\end{abstract}

Correspondence to: Professor Henri Rochefort, ICM, 208 Rue des Apothicaires, 34298 Montpellier, France

E-mail: henri.rochefort@inserm.fr

*Contributed equally

Key words: acidic $\mathrm{pH}$, breast cancer, cathepsin D, plasminogen activator

\section{Introduction}

High expression and over-secretion of cathepsin D (cath D) have been shown in several independent studies to be associated with an increased risk of recurrence and metastasis in breast cancer (1-3). Since the inactive $52 \mathrm{kDa}$ procathepsin $\mathrm{D}$ is secreted by cancer cells both in culture under routine conditions at $\mathrm{pH} 7.4(4,5)$ and in pleural effusion of breast cancer $(6)$, its maturation in acidic compartment is required to be proteolytically active. In this investigation we raised two major questions. Are cancer cells, cultured at the extracellular $\mathrm{pH}$ of hypoxic solid tumors $(7,8)$ able to stimulate the cath D activity, and in this case, would cath $\mathrm{D}$ be able to activate the plasminogen activator system since a high uPA concentration in breast cancer cytosol was associated with poor prognosis $(9,10)$ ?

We therefore monitored serum-free culture conditions at pH 6.6 approaching the acidity of tumor microenvironments allowing the survival of invasive MDA-MB231 breast cancer cells without cell lysis. We then tested the effects of medium acidification mediated by cath $\mathrm{D}$ activity on the secretion of uPA, tissue-type plasminogen activator (tPA) and PA inhibitor-1 (PAI-1). The two secreted plasminogen activators and their activities were analysed in the presence or absence of pepstatin, a specific aspartyl protease inhibitor.

\section{Materials and methods}

Cell culture and preparation of conditioned media. MDAMB231 breast cancer cells were cultured in duplicate 6-well plates in Dulbecco's modified Eagle's medium (DMEM) with $10 \%$ fetal calf serum to $80 \%$ confluence. To test the effect of an acidic $\mathrm{pH}$ on lysosome distribution and cath $\mathrm{D}$ routing, cells were transferred on glass coverslips and medium was changed to a $50 \mathrm{mM}$ HEPES-buffered Ringer's solution with $70 \mathrm{mM}$ $\mathrm{Na}$ acetate as described (11). To prepare conditioned media during longer time of treatment, the cells were transferred in duplicate in 6-well plates in DMEM solution as described (12). Briefly, the culture medium was DMEM without FCS, with Hank's balanced salt solution. It was adjusted to $\mathrm{pH} 6.6$ 
or 7.4 using $\mathrm{HCO}_{3} / \mathrm{HCl}$ according to the equation $\left[\mathrm{HCO}_{3}\right]=$ $\left(1.52 \mathrm{mM}\right.$ of $\left.\mathrm{CO}_{2}\right) \times[10(\mathrm{pH} 6.24)]$. In experiments with pepstatin A $(50$ or $100 \mu \mathrm{M})$, this aspartyl protease inhibitor was dissolved in DMSO and its effect was compared to control media containing the same amount of DMSO alone. The $\mathrm{pH}$ of conditioned media measured before addition to the cells and at the end of incubation were controlled to be constant. Under these conditions, MDA-MB231 cells were viable for at least 4 days. Cell number was evaluated by DNA assay using the DABA colorimetric method (13).

Media conditioned by these cells during increasing periods of time were normalised to the number of cells (determined by DNA assay), and centrifuged to remove cell debris. The supernatant was then layered on a PAGE for zymography or western blot analysis or were assayed for tPA activity and for tPA and PAI-1 antigen concentrations.

Analysis of plasminogen activators (PA) activity by casein-plasminogen zymography. PA activity was analysed after separation by electrophoresis in $10 \%$ polyacrylamide SDS gel copolymerized with $1 \mathrm{mg} / \mathrm{ml}$ of casein (Sigma, St. Louis, MO, USA) and $30 \mu \mathrm{g} / \mathrm{ml}$ human plasminogen (Sigma) under non-reducing conditions (without mercaptoethanol) and in the absence of serine protease inhibitors, as described $(14,15)$. The caseinolytic bands were revealed and quantified by scanning. Molecular weight markers (Amersham, Piscataway, NJ, USA) were run in parallel.

Plasminogen activator enzymatic assay. PA activity in conditioned media was determined in triplicate using the human PA chromogenic enzymatic kit (Assay pro ref CT1001, AssaySense, St. Charles, MO, USA) according to instructions of this laboratory. This assay was not specific for tPA or uPA. Briefly, plasmin produced from plasminogen activation was quantified using a specific plasmin substrate releasing para-nitroaniline, a yellow chromophore. Amiloride (1 mM), which inhibits uPA activity, was used to discriminate tPA activities (16). The plate was incubated at $37^{\circ} \mathrm{C}$ in a humid incubator for increasing periods of time. The optical density at $405 \mathrm{~nm}$ determined using a microplate spectrophotometer MRX (Dynatech Laboratories, Chantilly, VA, USA) and checked to be proportional to PA activities.

Western blot analysis of tPA concentration. The 3-day conditioned media were prepared from MDA-MB231 cells as described above, supplemented with protease inhibitors (Complete, Roche Diagnostics, Meylan, France), and $5 \mathrm{mM}$ mercaptoethanol and concentrated 20-fold using $10 \mathrm{~K}$ Amicon Ultra- $0.5 \mathrm{ml}$ (Millipore, Molsheim, France). A total of $10 \mu \mathrm{l}$ of concentrated media were analysed on 7.5\% SDS-PAGE and transferred to nitrocellulose as described (17). Membranes were probed with a rabbit polyclonal antibody to human tPA (ab28219 from Abcam, Paris, France) with 1:1,000 dilution. After washing, membranes were incubated with peroxidaseconjugated secondary antibody (dilution 1:5,000; Amersham) and revealed by bioluminescence with the ECL detection system (Amersham). The apparent molecular weights were estimated with pre-stained standard proteins (Bio-Rad, Marnes-laCoquette, France) run in parallel. Intracellular protein amounts were quantified by the Bradford method.
tPA and PAI-1 ELISA assays. The Imubind tPA and PAI-1 ELISA kits (American Diagnostica GmbH, Pfungstadt, Germany) were used according to manufacturer's instructions. Briefly, tPA or PAI-1 antigens were retained on a goat polyclonal antibody anti-tPA or a mouse monoclonal anti-PAI-1 adsorbed on the microtiter plate and quantified by a second peroxidase-conjugated polyclonal anti-tPA or anti-PAI-1 antibody. The concentrations of tPA and PAI-1 in the samples were determined by plotting the values of peroxidase activities to a standard curve obtained from purified antigens.

Degradation of PAI-1 by cath D. Recombinant active PAI-1 $(\sim 43 \mathrm{kDa})$ and cath $\mathrm{D}$ from human liver $(\sim 34 \mathrm{kDa})$ were purchased from Sigma-Aldrich (Lyon, France). The ability of cath D to cleave PAI-1 was investigated with an enzyme:substrate ratio of 1:5 in a $100 \mu \mathrm{M}$ sodium acetate buffer at $37^{\circ} \mathrm{C}$ at $\mathrm{pH} 6.0,5.2$ or 4.0 as previously described (23). Inhibition of this digestion was performed with pepstatin at $0.1 \mu \mathrm{M}$. After the indicated time of incubation, the reaction was stopped by freezing. Samples were then boiled in electrophoresis buffer for $3 \mathrm{~min}$, and fragments of PAI-1 were separated on a $12 \%$ polyacrylamide SDS-PAGE. The SDS-PAGE was stained with Brilliant Blue.

Immunolocalization of cath $D$ and validity of the cath $D$ antibodies. MDA-MB231 cells were cultured on glass coverslips at $\mathrm{pH} 7.4$ or 6.6 for $3 \mathrm{~h}$. They were then fixed with paraformaldehyde and glutaraldehyde and permeabilized by Triton X-100. Lysosomes vesicles were stained using the anti-cath D M1G8 mAb (18), the cath D swine polyclonal antibodies (kindly provided by Dr M. Fusek) or the anti-LAMP1 antibody (Abcam). The M1G8 mAb used (Figs. 1 and 2) recognises all forms of cath $\mathrm{D}$, while the M2E8 mAb is specific of the pro-enzyme. These antibodies have been characterized previously $(18,19$ and the references within).

\section{Results}

Effect of the acidic $p H$ on MDA-MB231 cells, lysosome localization and cath $D$ level. MDA-MB231 breast cancer cells were plated in 12-well plates to reach $30 \%$ confluence and then incubated in the FCS free media at pH 7.4 or 6.6 for up to 3 days. Their growth was decreased by $35 \%$ at $\mathrm{pH} 6.6$ compared to $\mathrm{pH} 7.4$, but not altered by pepstatin $\mathrm{A}$, at either $\mathrm{pH}$ value (results not shown). We have also verified that cells plated at $80 \%$ confluence, remained quiescent without cell lysis at $\mathrm{pH} 6.6$ for at least $36 \mathrm{~h}$ allowing the preparation of conditioned media for secreted proteins analysis (data not shown).

As shown on Fig. 1, the lysosomes stained by different cath D antibodies or Lamp1 antibodies, were delocalised at the cell periphery by medium acidification from $\mathrm{pH} 7.4$ (30\% at the cell periphery) to $\mathrm{pH} 6.6$ (70\% at periphery). The effect was progressive from $\mathrm{pH} 7.4$ to 6.3 and was optimal at $\mathrm{pH} 6.6$ which was chosen for further experiments. This peripheral location of lysosomes at pH 6.6 was rapid, within $7 \mathrm{~min}$ and stable for 3 days (Fig. 2). It was rapidly reversible at $\mathrm{pH} 7.4$ indicating that the cells were still viable (data not shown).

Zymography analysis of the cath D stimulation of the proteolytic activity of secreted plasminogen activators. The conditioned media of MDA-MB231 cells, collected after 1 


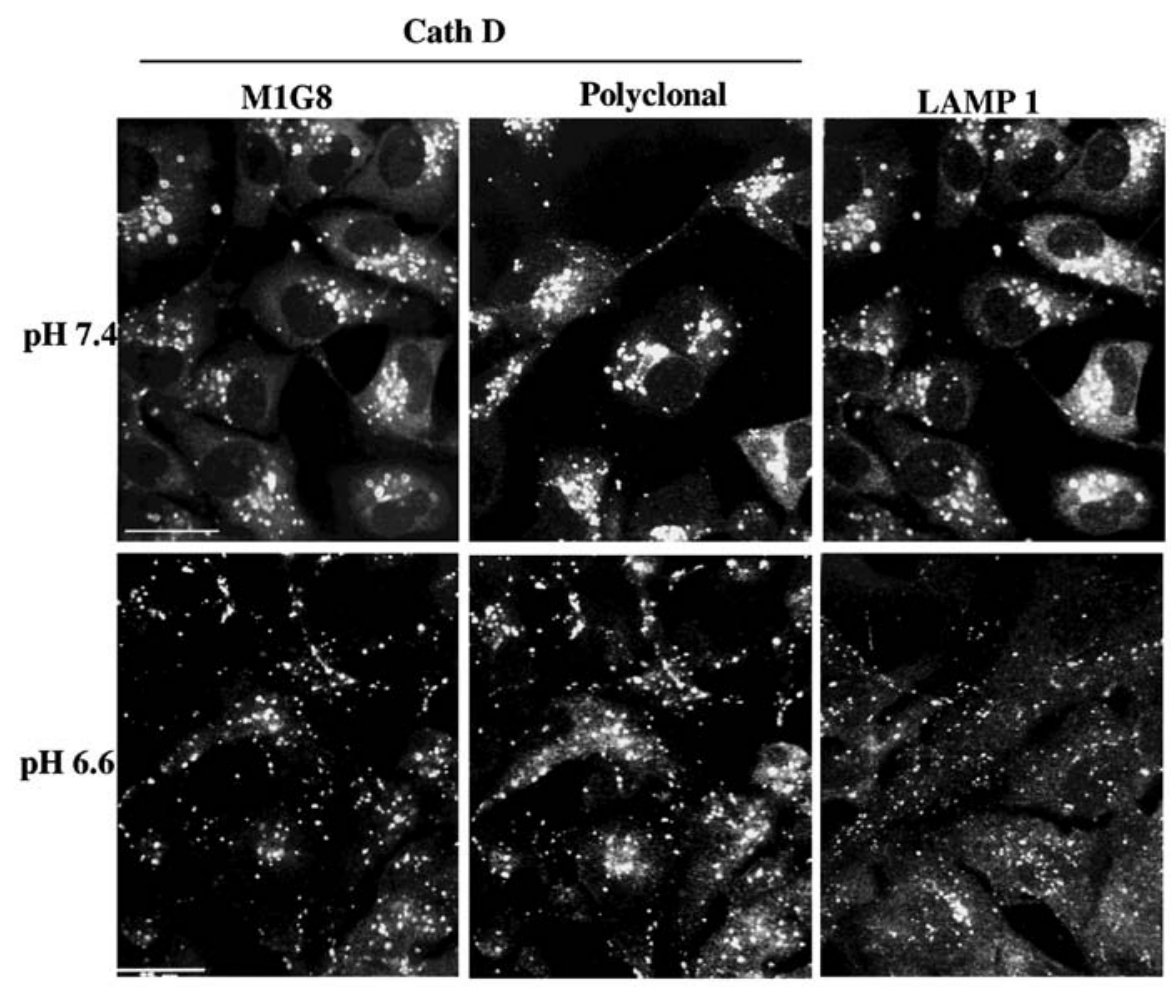

Figure 1. Representative photomicrographs showing the displacement of lysosomes at the cell periphery at pH 6.6. MDA-MB231 cells were cultured on glass coverslips at $\mathrm{pH} 7.4$ or 6.6 for $3 \mathrm{~h}$. They were then fixed with paraformaldehyde and glutaraldehyde and permeabilized by Triton X-100. Lysosomes were stained using the anti-cath D M1G8 mAb, the cath D polyclonal antibodies from Dako or the anti LAMP1 antibodies. The displacement of vesicles from the peri-nuclear region at $\mathrm{pH} 7.4$ to the cell periphery at $\mathrm{pH} 6.6$ is shown with the 3 antibodies.

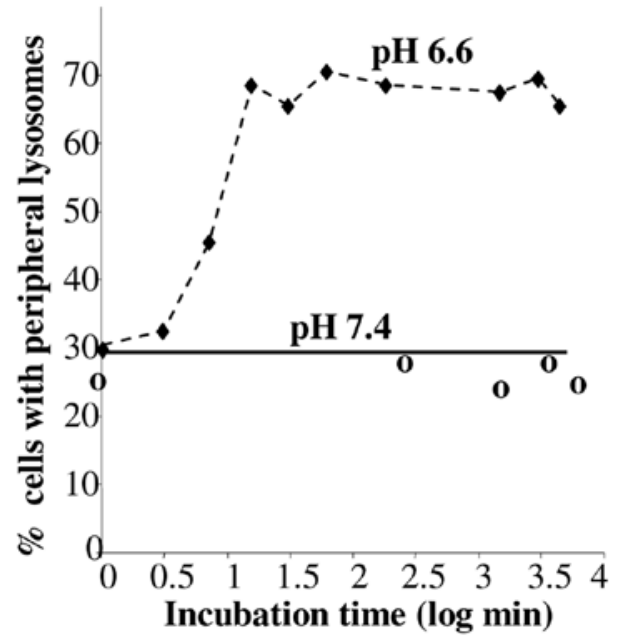

Figure 2. Time course of peripheral delocalization of lysosomes by acidic $\mathrm{pH}$. The peripheral delocalization of lysosomes was rapid at $\mathrm{pH}$ 6.6. Quantification was as in Fig. 1 and in Materials and methods.

to 3 days of culture at $\mathrm{pH} 7.4$ or 6.6 , were analysed for PA activities on a non-reducing SDS-PAGE containing plasminogen and casein as described in Materials and methods. In acidic and neutral media the same caseinolytic large bands were observed migrating with apparent molecular weight of 110-130, 63-75 and 45 kDa. However, when cells had been treated with pepstatin, the caseinolytic bands of higher molecular weight $(63-75 \mathrm{kDa})$ were decreased in acidic conditions but $45 \mathrm{kDa}$ bands were unaffected (Fig. 3). The molecular weights of the cath D stimulated bands were in agreement with those of the unbound tPA $(63-75 \mathrm{kDa})$ and of a PA/PAI-1 complex (110-130 kDa) $(16,20,21)$. The absence of caseinolytic bands in PAGE analysis performed in the same experiments without plasminogen (Fig. 3A, lanes 9 and 10) or without conditioned media showed an effect due to the activation of plasminogen rather than the activation of other proteases secreted or present in the gel. The $45 \mathrm{kDa}$ band (Fig. 3) corresponded to uPA on the basis of its molecular weight and specific sensitivity to amiloride $(16,22)$ as shown in Fig. 4. This band was not modified by pepstatin treatment suggesting that uPA activity was not stimulated by cath D activity (Figs. 3 and 4). Quantification by scanning of lanes 1 to 4 of the zymograph (Fig. 3A) showed that after 3 days of conditioning, the activity of the different molecular weight PA forms, was decreased at the acidic $\mathrm{pH}$ (Fig. 3B). This decreased PA-induced caseinolytic activity at pH 6.6 compared to $\mathrm{pH} 7.4$ was reproducibly observed in independent experiments (Fig. 5) and was associated with a decrease of the secreted cath D (see previous section). Fig. 3B also shows that pepstatin decreased specifically the 75 to $63 \mathrm{kDa}$ activities at $\mathrm{pH} 6.6$ but not at $\mathrm{pH} 7.4$ while the uPA activities were not altered. The effect of pepstatin on the 63-75 kDa lytic bands was slow and optimal after 3 days of treatment (Fig. 5).

Effect of pepstatin at pH 6.6 on the activity and protein level of tPA and PAI-1 in the conditioned media. The effect of pepstatin on the PA proteolytic activity of conditioned media 


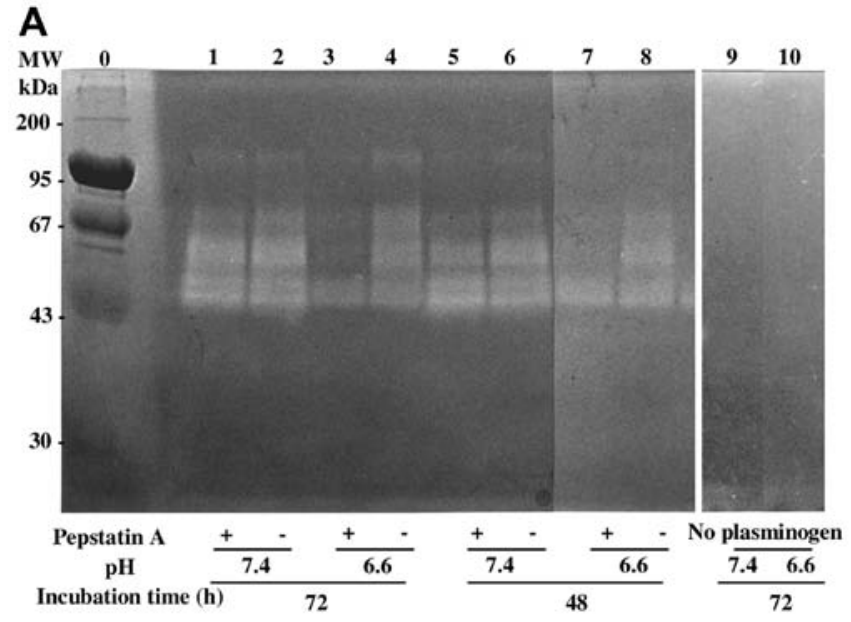

B

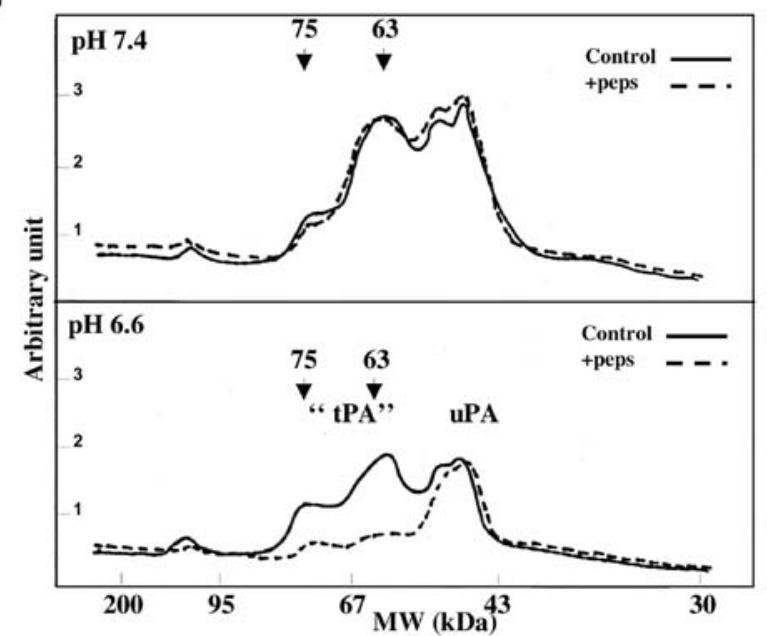

Figure 3. Zymography of plasminogen activator activities in media conditioned by MDA-MB231 cells. (A) Conditioned media prepared at $\mathrm{pH} 7.4$ or 6.6 were analysed by non-reducing SDS-PAGE as described in Materials and methods. Lanes 1 to 8, results after 2 and 3 days of incubation with or without pepstatin A. Control experiments without added plasminogen (lanes 9 and 10) or at time 0 of incubation (not shown), indicated that the caseinolytic activity was dependent of plasminogen and media conditioned by MDA-MB231 cells. Molecular weights were estimated from the migration of standard proteins. (B) The activities of the different molecular weight PA forms were quantified by scanning the zymograph (A; lanes 1 to 4 ). Their secretion was decreased at an acidic $\mathrm{pH}$ where pepstatin decreased specifically the 75-63 kDa forms but not the $45 \mathrm{kDa}$ form.

was also evaluated by a PA colorimetric assay. After 3 days of culture at $\mathrm{pH}$ 6.6, the total PA activity and the amiloride resistant tPA activity were partly inhibited by pepstatin (Table I, compare lanes a and b).

In order to confirm that the effect of cath D was not due to an increase of the secreted tPA, we estimated its concentration using western immunoblot analysis. As shown in Fig. 6A, the human tPA present as a large $75 \mathrm{kDa}$ band appeared unaffected in the presence of pepstatin at $\mathrm{pH}$ 6.6. Excluding a non-specific $55 \mathrm{kDa}$ band also revealed with the secondary antibodies alone (lanes 4-6), the tPA antibodies recognised at $\mathrm{pH} 7.4$ a $75 \mathrm{kDa}$ band corresponding to tPA and a predominant $110 \mathrm{kDa}$ band corresponding to tPA/PAI-1 inhibitor complexes (lane 1) as previously described $(20,21)$. At $\mathrm{pH} 6.6$ the amount of the secreted tPA was decreased compared to $\mathrm{pH} 7.4$, but pepstatin

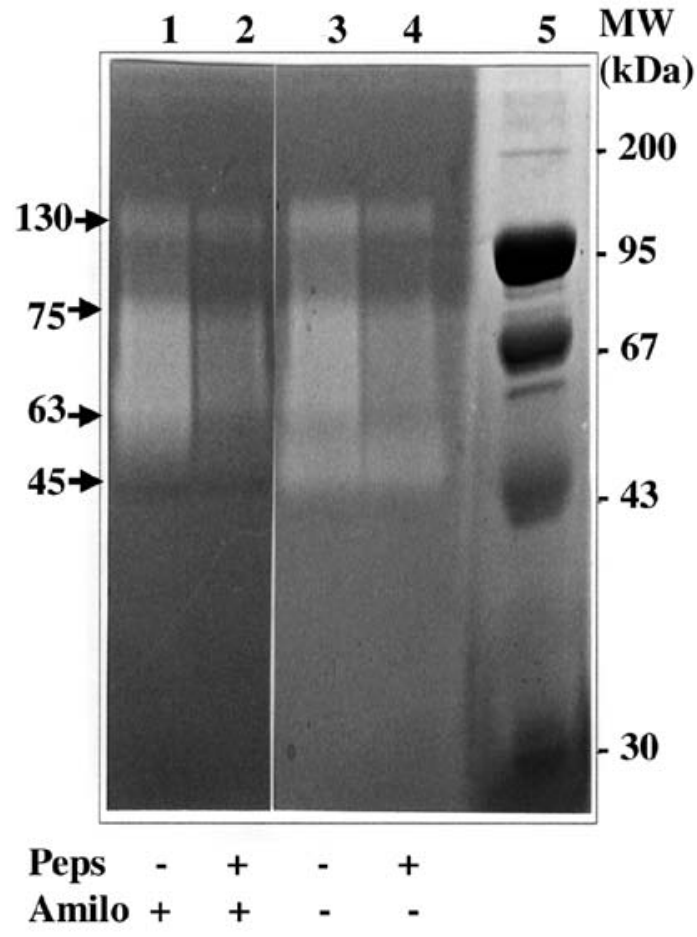

Figure 4. Effect of amiloride on the PA activities. Conditioned media were prepared as described in Fig. 3A (lanes 3 and 4) after a 3-day culture at pH 6.6. This experiment confirms the inhibition of the 63-75 $\mathrm{kDa}$ form and shows the specific decrease by amiloride of the $45 \mathrm{kDa}$ activity corresponding to the urokinase-plasminogen activator (uPA) but not that of the 63-75 kDa form. Lane 5, molecular weight markers.

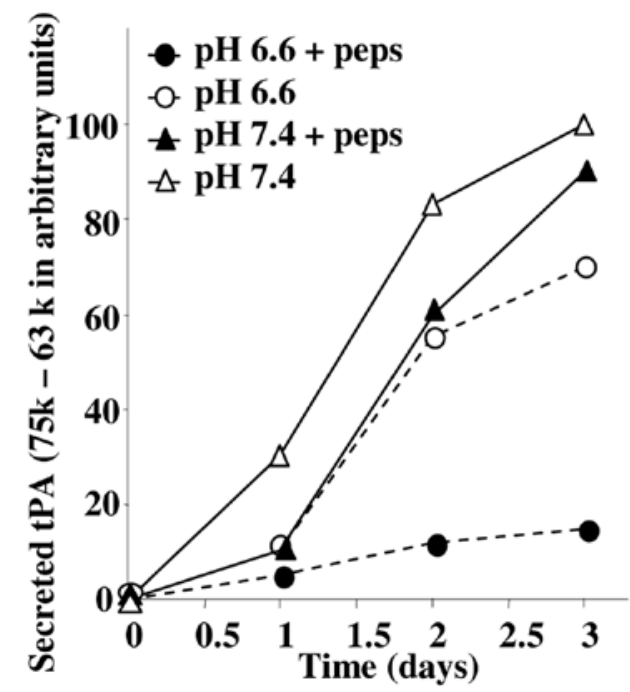

Figure 5. Time course of the tPA activity secreted in the conditioned media Culture media were conditioned for increasing periods of time at the two $\mathrm{pH}$ values and analysed by zymography. The amount of tPA was estimated by scanning of the 75-63 kDa region of the zymograph as described in Fig. 3 and represented in function of the time of secretion at $\mathrm{pH} 7.4$ or 6.6 , respectively.

had no effect on the level of the $75 \mathrm{kDa}$ band (Fig. 6). While the $110 \mathrm{kDa}$ entity was predominant at $\mathrm{pH} 7.4$, (lane 1) it was not seen at pH 6.6 (lanes 2 and 3) which is consistent with a dissociation of the tPA/PAI-1 inhibitor complex facilitated 
Table I. Effect of pepstatin on PA activities, tPA and PAI-1 concentrations secreted by MDA-MB-231 cells at pH 6.6.

Cell medium after

$72 \mathrm{~h}$ culture at $\mathrm{pH} 6.6$
Cell medium after

$72 \mathrm{~h}$ culture at $\mathrm{pH} 6.6$

$+10^{4} \mathrm{M}$ pepstatin
Student's t-test: p-value
1) PA activity $\%$ control $\pm \mathrm{SD}$

2) tPA activity (amiloride resistant) $\%$ control \pm SD

3) tPA level in $\mathrm{ng} / \mathrm{mg}$ protein

4) PAI-1 level in $\mathrm{ng} / \mathrm{mg}$ protein

$100.0 \pm 15.3(2)$

$100.0 \pm 29.5(6)$

$9.86 \pm 0.73(3)$

$269.3 \pm 10.9(3)$

$60.0 \pm 7.3^{\mathrm{a}}(2)$
$68.0 \pm 14.7^{\mathrm{a}}(6)$
$11.02 \pm 0.52^{\mathrm{a}}(3)$
$405 \pm 17.0^{\mathrm{b}}(3)$

0.06

0.048

0.039 0.00001

MDA-MB-231 cells were incubated in triplicates for $72 \mathrm{~h}$ in serum-free medium at $\mathrm{pH} 6.6$ with or without $10^{-4} \mathrm{M}$ pepstatin. Conditioned media were prepared as in Materials and methods for zymography, they were not concentrated but centrifuged to remove eventual detached cells. They were assayed for total PA activities by the PA chromogenic activity Zymutest assay, 1) without amiloride or 2) for tPA activities in the presence of $1 \mathrm{mM}$ amiloride. The amiloride resistant PA corresponded to about $30 \%$ of the total PA activity. Results are in $\%$ of the activity without pepstatin. 3) tPA antigen concentrations were assayed by the Imubind tPA ELISA kit. 4) PAI-1 concentrations were assayed by the ELISA Femtelle kit and expressed per $\mathrm{mg}$ of total secreted protein. Values were obtained from 3 independent experiments and triplicate assays for each experiment. ${ }^{a}$ The pepstatin effect is at the limit of significance. ${ }^{\mathrm{b}} \mathrm{A}$ highly significant pepstatin effect.
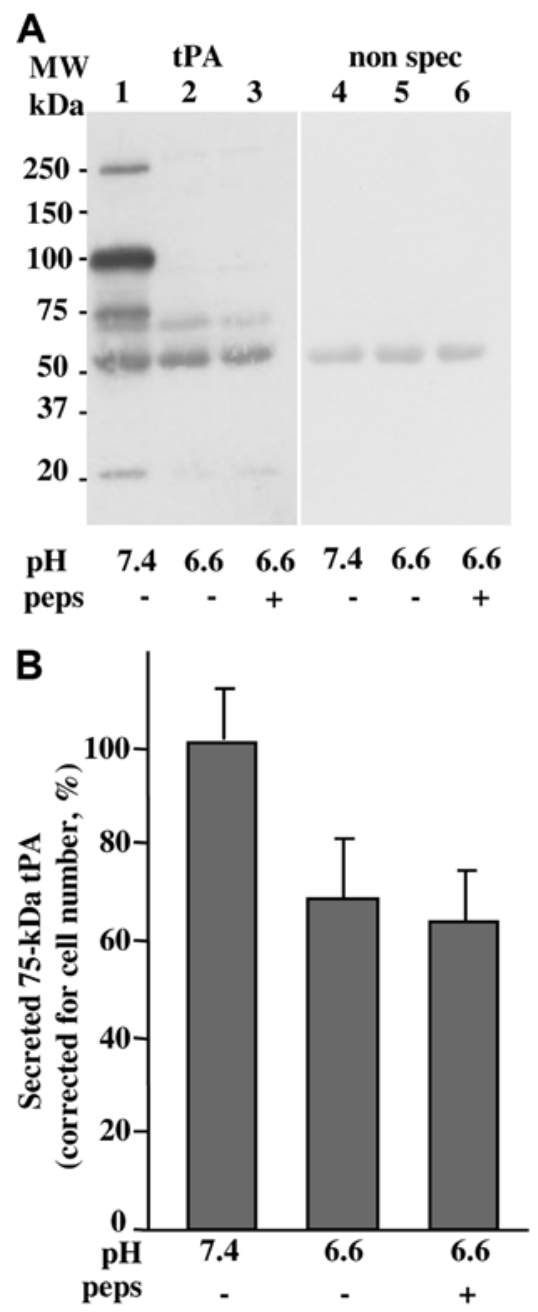

Figure 6. Western blot analysis of tPA secreted by MDA-MB231 cancer cells. The media conditioned by MDA-MB231 cells for 3 days at $\mathrm{pH} 7.4$ and 6.6 and with or without $10^{-4} \mathrm{M}$ pepstatin were analyzed by western blotting as described in Materials and methods. (A) Concentrated media were analysed on $7.5 \%$ SDS-PAGE and transferred to nitrocellulose. Membranes were probed with a rabbit polyclonal antibody to human tPA (lanes 1-3) or by the secondary antibody (lanes 4-6). (B) Histogram of western blotting after scanning analysis in PC-Bas 2.0 software (Fuji, USA) and corrected for the same cell number and protein content.

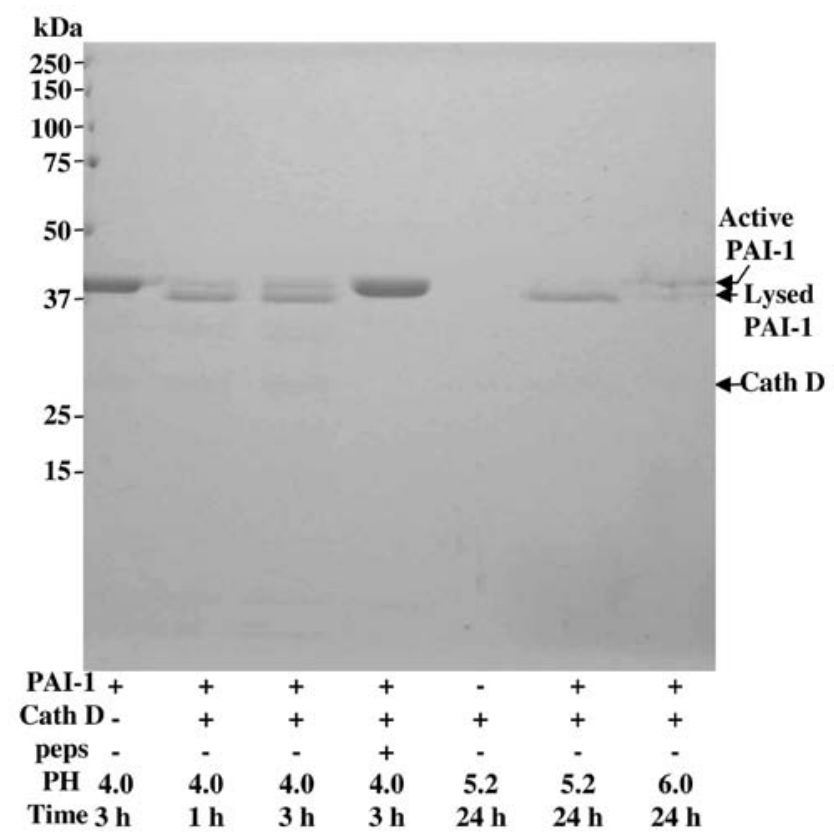

Figure 7. Active PAI-1 is proteolysed by cath D. Cleavage of PAI-1 by cath D was performed by incubating PAI-1 with cath D (enzyme-to-substrate ratio 1:5) at $37^{\circ} \mathrm{C}$ as described in Materials and methods. SDS-PAGE performed under reducing conditions was colored with Brillant Blue.

at an acidic $\mathrm{pH}$ as shown previously $(14,15,25)$. The contrast between the larger lytic bands ( 75 to $63 \mathrm{kDa}$ ) of the zymography experiments, compared to the distinct $75 \mathrm{kDa}$ bands of the western blot analysis, might be due to the absence of added serine protease inhibitors and mercaptoethanol in the zymograpy experiments.

These data suggest that the mechanism of the cath D activation of tPA was probably indirect and due to the degradation of a tPA inhibitor by cath D. We demonstrate that pepstatin markedly increased PAI-1 concentration in the same conditioned media (Table I, line 4). PAI-1 degradation by cath D has been previously described in monocytes at a more acidic condition 
(23). We complete these data in Fig. 7 by finding that cath D slowly degraded pure PAI-1 even at $\mathrm{pH} 6.0$ in a cell free system. Collectively, these data indicate that cath D increased the activity of secreted plasminogen activators (PA) at acidic $\mathrm{pH}$ and decreased in the same conditions the level of PAI-1.

\section{Discussion}

This study aimed to specify whether the weak acidity (pH 6.5 to 6.7) of the extracellular milieu of hypoxic solid tumors $(7,8)$ allows the activation of pro-cath D and alters the secreted activities of plasminogen activators.

We show that under a weakly acidic condition,MDA-MB231 cells were able to survive and to secrete a proteolytically active cath $\mathrm{D}$. Therefore, in addition to its mitogenic activity as a ligand at a neutral $\mathrm{pH}(24)$, cath $\mathrm{D}$ can also be activated as a protease when breast cancer cells are exposed to an extracellular $\mathrm{pH}$ of 6.6. This mild acidic $\mathrm{pH}$ can be observed in vivo in aggressive solid tumors $(12,25)$.

At $\mathrm{pH}$ 6.6, cath D stimulated the liberation in the culture medium of an active plasminogen activator resistant to amiloride and corresponding most likely to tPA. The MDA-MB231 cells are more aggressive and more efficient than MCF7 cells in spontaneously acidifying an extracellular milieu (12). They overexpress constitutively cath D (5) corresponding to a basal-type breast cancer. By contrast the estrogen receptor positive luminal type MCF7 cells require estradiol to express and secrete both pro-cath D (5) and tPA (26). We show here that the MDA-MB231 cells secrete both tPA, uPA and PAI1 and that cath D can increase PA activities via its proteolytic activity inhibited by pepstatin.

The monolayer cell culture on plastic, used in our study, is far from the in vivo condition. However, the cath D effect on PA activity might even be more important in vivo and within the microenvironment of a solid tumor. Actually both tPA activity and tumor aggressiveness were markedly increased in MDA-MB231 cells after their in vivo passage as orthotopic xenograft tumors in mice, indicating that the rodent microenvironment including stromal and endothelial cells, cooperated to increase tPA activity (27).

We show here additional evidence that cath $\mathrm{D}$ can be activated in vivo to behave as a protease. Previous reports showed that cath D in MCF7 cells stimulated FGF2 cellular uptake from an embedded extracellular matrix (28). Conversely, the addition of a KDEL retention signal for endoplasmic reticulum to pre-procath $\mathrm{D}$, inhibited in vivo both cath $\mathrm{D}$ maturation and experimental metastasis in mice (29) underlining the requirement of a proteolytic activity to stimulate metastasis.

The mechanisms of the presence of secreted active forms of cath D and of its specific effect on PA activities are not fully understood. Active secreted cath D could be due to the auto-activation of procath $\mathrm{D}$ by removal of its pro-fragment (30) or to the rapid displacement of lysosomes at the cell periphery facilitating the secretion of lysosomal active cath D (Figs. 1 and 2). Whether this rapid lysosome delocalisation explains the secretion of mature cath $\mathrm{D}$ in the medium as proposed for cath B secretion (31) was not investigated in the present study.

The mechanism of the increased activity of the secreted tPA by cath $\mathrm{D}$ is not due to an increased amount of tPA, as shown by western blot analysis and immunoassay of the antigen. Since the zymogen and the two-chains forms of tPA display similar activity $(32,33)$, the most likely explanation is that the effect of cath D is indirect. In fact the secreted PAI-1 is in large excess compared to PA in several cell lines (34) and modulation of tPA activity by PAI-1 is central in endothelial cells (35). Moreover, PAI-1 is a specific substrate of cath D, but not of cysteinyl cathepsins, as shown in human monocytes (23). The fact that we show here at $\mathrm{pH} 6.6$ a significant increase of PAI-1 with pepstatin and the proteolysis of recombinant PAI-1 by cath D supports an indirect stimulation of the secreted PA activity via PAI-1 proteolysis. It is however intriguing that the degradation of PAI- 1 by cath D stimulates specifically tPA activity measured by zymography while cath $\mathrm{D}$ appears to stimulate both uPA and tPA activities (compare lines 1 and 2 of Table I) when measured in the conditioned media before separation of the two enzymes by electrophoresis (Table I). This might be due to a different affinity of PAI-1 for tPA and for uPA (36). However, we cannot exclude other mechanisms at the cell surface where several receptors bind these proteases, such as the Annexin II/plasminogen receptor (37) and the LRP receptor which can bind both tPA/PAI-1 complex (38) and cath D (39).

The cath D proteolytic activity facilitating indirectly PA activation completes the scheme of a very complex proteolytic network leading to the stimulation of invasion, angiogenesis and tumor growth (40). Procath D can be autoactivated in vitro at an acidic $\mathrm{pH}(4,5,30)$ to trigger a proteolytic cascade when liberated with other proteases in the extracellular milieu of tumors. Activation of procathepsin B (41) and procathepsin L (42) by cath $\mathrm{D}$ had been shown in vitro but at the more acidic $\mathrm{pH}$ found in lysosomes, thus limiting its biological significance. This study introduces tPA as an additional partner in this complex proteolytic cascade to modulate invasion, metastasis and angiogenesis.

The significance and role of tPA and PAI-1 in cancer is debated (43). On one hand, several experimental studies indicate that IPA facilitates tumor progression and several mechanisms have been proposed $(27,39,44,45)$. Gene invalidation in mouse showed that tPA cooperates with uPA in stimulating cell survival (46). However, clinical studies have underlined tPA level as a marker of good prognosis in breast cancer $(47,48)$ in contrast to uPA $(9)$. The reason for these discrepancies is not currently understood. Moreover, PAI-1 by inhibiting tPA activity has also been proposed to decrease the stress-induced senescence activity of the wild-type p53 (49). Thus cath D, by degrading PAI-1 and IGF-BP3 (50), might also interfere with the PAI-1/IGF-BP3 cascade (51) to stimulate cancer cells.

To conclude, we show here that cath $\mathrm{D}$ in breast cancer cells at $\mathrm{pH}$ 6.6, but not at neutral $\mathrm{pH}$, stimulates as a protease the activity of secreted plasminogen activators probably by degrading PAI-1. This effect might also take place in vivo in poorly vascularised regions of solid tumors to modulate invasion and tumor growth.

\section{Acknowledgements}

This study was supported by INSERM and University of Montpellier 1. R.F. was a recipient of the Association pour la Recherche sur le Cancer. We are grateful to Dr Y. Hayashido 
for his advice on zymography, to M. Gleizes for technical assistance, to C. Viglianti and S. Roques for tPA enzymatic assays and to J.-Y. Cance for the skilful preparation of the figures.

\section{References}

1. Spyratos F, Brouillet JP, Defrenne A, et al: Cathepsin-D: an independant prognostic factor for metastasis of breast cancer Lancet 8672: 1115-1118, 1989.

2. Foekens JA, Look MP, Bolt-de Vries J, Meijer-van Gelder M, van Putten WLJ and Klijn JGM: Cathepsin D in primary breast cancer: prognostic evaluation involving 2810 patients. Br J Cancer 79: 300-307, 1999.

3. Rochefort H, Garcia M, Glondu M, Laurent V, Liaudet E, Rey JM and Roger P: Cathepsin D in breast cancer: mechanisms and clinical applications a 1999 overview. Clinica Chimica Acta 291: 157-170, 2000.

4. Capony F, Rougeot C, Montcourier P, Cavaillès V, Salazar G and Rochefort $\mathrm{H}$ : Increased secretion altered processing, and glycosylation of pro-cathepsin D in human mammary cancer cells. Cancer Res 49: 3904-3909, 1989.

5. Rochefort H, Capony F and Garcia M: Cathepsin D: a protease involved in breast cancer metastasis. Cancer Metastasis Rev 9: 321-331, 1990.

6. Veith FO, Capony F, Garcia M, Chantelard J, Pujol H, Veith F, Zajdela A and Rochefort H: Release of estrogen-induced glycoprotein with a molecular weight of 52,000 by breast cancer cells in primary culture. Cancer Res 43: 1861-1868, 1983.

7. Stubbs M, McSheehy PM and Griffiths JR: Causes and consequences of acidic pH in tumors: a magnetic resonance study. Adv Enzyme Regul 39: 13-30, 1999.

8. Martin GR and Jain RK: Measurement of interstitial $\mathrm{pH}$ profiles in normal and neoplastic tissue using fluorescence ratio imaging microscopy. Cancer Res 54: 5670-5674, 1994.

9. Foekens JA, Peters HA, Look MP, et al: The urokinase system of plasminogen activation and prognosis in 2,780 breast cancer patients. Cancer Res 60: 636-643, 2000.

10. Harbeck N, Schmitt M, Meisner C, et al: Ten-year analysis of the prospective multicentre Chemo-NO trial validates American Society of Clinical Oncology (ASCO)-recommended biomarkers uPA and PAI-1 for therapy decision making in nodenegative breast cancer patients. Eur J Cancer 49: 1825-1835, 2013.

11. Heuser J: Changes in lysosome shape and distribution correlated with changes in cytoplasmic $\mathrm{pH}$. J Cell Biol 108: 855-864, 1989

12. Montcourrier P, Silver IA, Farnoud R, Bird I and Rochefort H: Breast cancer cells have a high capacity to acidify extracellular milieu by a dual mechanism. Clin Exp Metastasis 15: 382-392, 1997.

13. Chalbos D, Vignon F, Keydar I and Rochefort H: Estrogens stimulate cell proliferation and induce secretory proteins in a human breast cancer cell line (T47D). J Clin Endocrin Metab 55: 276-283, 1982

14. Martínez-Zaguilán R, Seftor EA, Seftor RE, Chu YW, Gillies RJ and Hendrix MJ: Acidic $\mathrm{pH}$ enhances the invasive behavior of human melanoma cells. Clin Exp Metastasis 14: 176-186, 1996.

15. Heussen $C$ and Dowdle EB: Electrophoretic analysis of plasminogen activators in polyacrylamide gels containing sodium dodecyl sulfate and copolymerized substrates. Anal Biochem 102: 196-202, 1980.

16. Vassalli JD and Belin D: Amiloride selectively inhibits the urokinase-type plasminogen activator. FEBS Lett 214: 187-191, 1987.

17. Maynadier M, Ramirez JM, Cathiard AM, et al: Unliganded estrogen receptor alpha inhibits breast cancer cell growth through interaction with a cyclin-dependent kinase inhibitor (p21(WAF1)). FASEB J 22: 671-681, 2008.

18. Garcia M, Capony F, Derocq D, Simon D, Pau B and Rochefort H: Characterization of monoclonal antibodies to the estrogen-regulated $\mathrm{Mr}$ 52,000 glycoprotein and their use in MCF7 cells. Cancer Res 45: 709-716, 1985.

19. Brouillet JP, Spyratos F, Hacene K, Fauque J, Freiss G, Dupont F, Maudelonde T, Rochefort H: Immunoradiometric assay of pro-cathepsin $\mathrm{D}$ in breast cancer cytosol: relative prognostic value versus total cathepsin D. Eur J Cancer 29A: 1248-1251, 1993.

20. Tissot JD, Hauert J and Bachmann F: Characterization of plasminogen activators from normal human breast and colon and from breast and colon carcinomas. Int J Cancer 34: 295-302, 1984.
21. Christensen L, Wiborg Simonsen AC, Heegaard CW, Moestrup SK, Andersen JA and Andreasen PA: Immunohistochemical localization of urokinase-type plasminogen activator, type-1 plasminogen-activator inhibitor, urokinase receptor and $\alpha 2$-macroglobulin receptor in human breast carcinomas. Int J Cancer 66: 441-452, 1996.

22. Jankun J and Skrzypczak-Jankun E: Molecular basis of specific inhibition of urokinase plasminogen activator by amiloride. Cancer Biochem Biophys 17: 109-123, 1999.

23. Simon DI, Xu H and Vaughan DE: Cathepsin D-like aspartyl protease activity mediates the degradation of tissue-type plasminogen activator/plasminogen activator inhibitor-1 complexes in human monocytes. Biochim Biophys Acta 1268: 143-145, 1995.

24. Rochefort H and Liaudet-Coopman E: Cathepsin D in cancer metastasis: a protease and a ligand. Acta Pathol Microb Immunol Scand 107: 86-95, 1999.

25. Rofstad K, Mathiesen B, Kindem K and Galappathi K: Acidic extracellular $\mathrm{pH}$ promotes experimental metastasis of human melanoma cells in athymic nude mice. Cancer Res 66: 6699-6707, 2006.

26. Ryan TJ, Seeger JI, Kumar SA and Dickerman HW: Estradiol preferentially enhances extracellular tissue plasminogen activators of MCF-7 breast cancer cells. J Biol Chem 259: 14324-14327, 1984.

27. Jessani N, Humphrey M, McDonald WH, et al: Carcinoma and stromal enzyme activity profiles associated with breast tumor growth in vivo. Proc Natl Acad Sci USA 101: 13756-13761, 2004.

28. Briozzo P, Badet J, Capony F, Pieri I, Montcourrier P, Barritault D and Rochefort H: MCF7 mammary cancer cells respond to bFGF and internalize it following its release from extracellular matrix: a permissive role of cathepsin D. Exp Cell Res 194: 252-259, 1991.

29. Liaudet E, Garcia M and Rochefort H: Cathepsin D maturation and its stimulatory effect on metastasis are prevented by addition of KDEL retention signal. Oncogene 9: 1145-1154, 1994.

30. Richo G and Conner GE: Proteolytic activation of human procathepsin D. Adv Exp Med Biol 306: 289-296, 1991.

31. Rozhin J, Sameni M, Ziegler G and Sloane BF: Pericellular pH affects distribution and secretion of cathepsin B in malignant cells. Cancer Res 54: 6517-6525, 1994

32. Tate KM, Higgins DL, Holmes WE, Winkler ME, Heyneker HL and Vehar GA: Functional role of proteolytic cleavage at arginine-275 of human tissue plasminogen activator as assessed by site-directed mutagenesis. Biochemistry 26: 338-343, 1987.

33. Berg DT and Grinnell BW: Signal and propeptide processing of human tissue plasminogen activator: activity of a pro-tPA derivative. Biochem Biophys Res Commun 179: 1289-1296, 1991.

34. Cajot JF, Kruithof EK, Schleuning WD, Sordat B and Bachmann F: Plasminogen activators, plasminogen activator inhibitors and procoagulant analyzed in twenty human tumor cell lines. Int J Cancer 38: 719-727, 1986.

35. Suzuki Y, Mogami H, Ihara $\mathrm{H}$ and Urano T: Unique secretory dynamics of tissue plasminogen activator and its modulation by plasminogen activator inhibitor-1 in vascular endothelial cells. Blood 113: 470-478, 2009

36. Rijken DC, Hoegee-de Nobel E, Jie AF, Atsma DE, Schalij MJ and Nieuwenhuizen W: Development of a new test for the global fibrinolytic capacity in whole blood. J Thromb Haemost 6: $151-157,2008$

37. Sharma M, Ownbey RT and Sharma MC: Breast cancer cell surface annexin II induces cell migration and neoangiogenesis via tPA dependent plasmin generation. Exp Mol Pathol 88: 278-286, 2010.

38. Krieger M and Herz J: Structures and functions of multi-ligand lipoprotein receptors: macrophage scavenger receptors and LDL receptor-related protein (LRP). Annu Rev Biochem 63: 601-637, 1994

39. Beaujouin M, Prébois C, Derocq D, et al: Pro-cathepsin D interacts with the extracellular domain of the beta chain of LRP1 and promotes LRP1-dependent fibroblast outgrowth. J Cell Sci 123: 3336-3346, 2010

40. Mason SD and Joyce JA: Proteolytic networks in cancer. Trends Cell Biol 4: 228-237, 2011.

41. Pagano M, Capony F and Rochefort H: Pro-cathepsin D can activate in vitro pro-cathepsin B secreted by ovarian cancers. C R Acad Sci III. 309: 7-12, 1989 (In French). 
42. Nishimura Y, Kawabata T, Furuno K and Kato K: Evidence that aspartic proteinase is involved in the proteolytic processing event of procathepsin L in lysosomes. Arch Biochem Biophys 271: 400-406, 1989

43. Danø K, Behrendt N, Hoyer-Hansen G, Johnsen M, Lund LR, Ploug $\mathrm{M}$ and Romer J: Plasminogen activation and cancer. Thromb Haemost 93: 676-681, 2005.

44. Fredriksson L, Li H, Fieber C, Li X and Eriksson U: Tissue plasminogen activator is a potent activator of PDGF-CC. EMBO J 23: 3793, 2004.

45. Seeds NW, Basham ME and Haffke SP: Neuronal migration is retarded in mice lacking the tissue plasminogen activator gene. Proc Natl Acad Sci USA 96: 14118-14123, 1999.

46. Carmeliet P, Schoonjans L, Kieckens L, et al: Physiological consequences of loss of plasminogen activator gene function in mice. Nature 368: 419-424, 1994.

47. Duffy MJ, O'Grady P, Devaney D, O'Siorain L, Fennelly JJ and Lijnen HR: Tissue-type plasminogen activator, a new prognostic marker in breast cancer. Cancer Res 48: 1348-1349, 1988.
48. Chappuis P O, Dieterich B, Sciretta V, Lohse C, Bonnefoi H, Remadi S, and Sappino AP: Functional evaluation of plasmin formation in primary breast cancer J Clin Oncol 19: 2731-2738, 2001.

49. Kortlever RM, Higgins PJ and Bernards R: Plasminogen activator inhibitor-1 is a critical downstream target of p53 in the induction of replicative senescence. Nature Cell Biol 8: 877-884, 2006

50. Conover CA and De Leon DD: Acid-activated insulin-like growth factor-binding protein-3 proteolysis in normal and transformed cells. Role of cathepsin D. J Biol Chem 269: 7076-7080, 1994.

51. Elzi DJ, Lai Y, Song M, Hakala K, Weintraub ST and Shiio Y: Plasminogen activator inhibitor 1-insulin-like growth factor binding protein 3 cascade regulates stress-induced senescence. Proc Natl Acad Sci USA 109: 12052-12057, 2012. 